\title{
THE USE OF CODE-SWITCHING BY ENGLISH TEACHERS IN FOREIGN LANGUAGE CLASSROOM
}

\author{
Nur Maria Ulfah \\ Universitas Muhammadiyah Makassar \\ nurmaria.ulfah@ymail.com \\ Annisa Shofa Tsuraya \\ Universitas Islam Negeri Alauddin Makassar \\ annisa.tsuraya@uin-alauddin.ac.id \\ Risal \\ Universitas Muhammadiyah Makassar \\ duniaqsaja@gmail.com
}

\begin{abstract}
This research aimed at finding out; (1) types of code-switching used by English teachers in foreign language classroom, (2) the factors triggering the English teachers to use code-switching in the classroom, and (3) the functions of code-switching used by English teachers in the classroom. This research was conducted through descriptive qualitative method. The samples of the research consisted of 6 English teachers. In order to gather the data, the researcher used three instruments of research, they were: classroom observation, recorder, and interview. The types of code-switching appearing in the classroom were observed based on the theory proposed by Poplack, while the factors triggering the teachers to use code-switching in the classroom proposed by Holmes ${ }^{\text {ee }}$ theory, and the functions of code-switching in the classroom were perceived through the functions proposed by Sert. Moreover, to interpret the data gathered, the researcher analyzed them through three steps of analysis by using mode from Miles and Huberman, they were: data reduction, data description, and data classification. The findings indicated that the types of code-switching were simply found in three types: (a) inter-sentential code-switching (without inserting new information and which inserts new information), (b) intra-sentential code- switching (translation or word/phrase substitution within a sentence), and (d) tagswitching (interactional fillers code-switching). The factors triggering the English teachers to use code-switching in the classroom was found for four reasons, they are: (a) rhetoric reason, (b) differences of status and formalities, (c) quote other statements or proverbs, and (d) lack of vocabulary. And other factors gather from the classroom setting are: (a) the students $^{\text {ee }}$ ability in English are not the same, (b) code-switching emerges automatically or unconsciously, and (c) helping the students to share their ideas. Moreover, the functions of code-switching used by English teachers in the classroom were found for three functions; (a) topic switch, (b) affective function, and (c) repetitive function.
\end{abstract}

Keywords: Code-switching, EFL, English teacher, classroom

\section{INTRODUCTION}

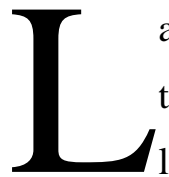
anguage is a system of communication. Language gives us the ability to let others know our thoughts and connect with various types of communication. One of the most important languages in the world recently is English. There are several reasons for such spread of English. One of these is socio-cultural, which relates to people's dependence on English for their wellbeing including politics, businesses, safety, entertainment, media and education. Therefore, English 
has become the language of communication in the world and then the need to learn English appears to make this communication easier.

English in Indonesia is as foreign language. Some experts when discussing teaching-learning English in language classrooms, two terms are used to describe them: English as a second language and English as a foreign language. ESL classrooms mean that the second language can serve as both the medium of instruction and the content of instruction, which means that the learner is expected to understand and communicate in second language. Besides, the students in the English as second language have change to practice the language in natural circumstances. In EFL classrooms, in contrast, the learner learns the language in an environment where there is little natural use of the language though they are expected to use the target language as the language teaching medium and for communication. Furthermore, the foreign language is treated equally to the other school subjects with its homework and test. The target language test is also become a requirement to finish the particular school grade.

In foreign language classrooms the language to be learned is both the target and as the instruction, even though, in addition to the target language usually there is another language present in the language classroom as well, it is usually the native language of the teachers and the learners. Because two languages exist in the classroom, it leads to a situation in which codes are switched. Therefore, code-switching is usually a natural part of language classroom interaction.

Code-switching is common practiced by the bilingual society as well as the students who are learning the foreign language from their surroundings. Code- switching could be allowed and used such the way to enrich the skill of communication. The bilingual society generally practices code switching to conceal their second language deficiency and to express their attitude and feeling toward the interlocutor, these intentions could be appeared in the language classroom too.

The use of code switching in foreign language classroom is still debatable. The experts who do not approve the use of code-switching in the language teaching think that code-switching only has disadvantage.

Gumperz and Hernandez (1972) claim that those who code-switch make a mess out of the conversation and cannot speak the language properly. Thomas (2001) maintains that in some communities code-switching is even seen as something unacceptable. However, there are experts who support the use of code- switching in the language teaching. Sert (2005) suggests that code-switching can be used for self-expression and is a way of modifying language for the sake of personal intentions. Sert suggests that code-switching can have a positive effect. When we code-switching, we build a bridge from the known, our native language to the unknown, target language. He claimed that this may have a vital and positive effect on foreign language learning.

Thus, because of the point of view about code-switching utility in the language classroom, the researcher was interested to find out the types of code-switching used by English teachers, the 
factors triggering the English teachers to use code-switching, and the functions of the code-switching used by English teachers in foreign language classroom.

\section{REVIEW OF LITERATURE}

Many researchers have been conducting studies related to this research. Offiong and Okon (2013) found that there are a number of possible reasons for the switching from one language to another and these will now be considered. The first is the notion the speaker may not to express him/herself in one language so switches to the others to compensate for the deficiency. As a result, the speaker may be triggered into speaking in their other language for a while. Secondly, switching commonly occurs when individual wishes to express solidarity with a particular social group. And the final is the alternation that occurs when the speaker wishes to convey his/her attitude to the listener. Where monolingual speakers can communicate these attitudes by means of variation in the level of formality in their speech, bilingual speakers can convey the same by code-switching.

Qing (2010) found that code-switching in language classroom is not always a blockage or deficiency in learning a language, but may be considered as a useful strategy in classroom interaction, if the aim is to make meaning clear and to transfer the knowledge to students in an efficient way. In another word, the use of code-switching somehow builds a bridge from unknown to known and may be considered as an important element in language teaching when used efficiently.

Jingxia (2010) found that code-switching to Chinese is a prevalent phenomenon in EFL classroom of Chinese universities, and it plays a significant role in English learning and teaching process.

Yletyinen (2004) found that both teachers and pupils employ code-switching in EFL classroom. However, there are differences in their uses of code- switching. The pupils mostly employ it from English to Finnish. In contrast to the teachers, who employ it from Finnish to English as well as from English to Finnish.

Shin (2005) found that the way Korean Sunday school teachers switch from English to Korean at particular junctures can be useful tool for maintaining and reinforcing children's Korean identity. The switch to a particular language in the bilingual discourse can be employed as an effective vehicle to signal ethnic identity.

The previous researchers above have similarity with this research. They mostly describe about the functions and advantages of the use of code-switching whether it is in second language classroom or foreign language classroom, while the differences are based on language that switched, such as Chinese to English, Finnish to English and Korean to English. All the researchers above agree that the existence of code-switching in the language classroom should not be evaded or denied. It can be a good device in maintaining classroom interaction and developing the students se awareness about the similarity and difference between the mother tongue and foreign language. Meanwhile, this research is focused on 
the use of code-switching by the teacher in foreign language classroom. This research tries to raise the awareness of the teacher in using code-switching in classroom. Besides that, this research is not only to find out the functions of code- switching but also to interpret the teachers ${ }^{\text {ee }}$ factors which triggered them in using code-switching in foreign language classroom.

\section{METHOD}

The method used in this research was descriptive qualitative method. It described the use of codeswitching by the teachers in English foreign language classroom. The researcher used total sampling technique where the population was also taken as the samples that consist of six English teachers in one of the best publics school in South Sulawesi. The instrument used in this research were observation, audio and video recording, and interview.

The researcher did in analyzing data was to identify the data which had gotten from the observation, recorder, and interview. The data was analyzed by using the descriptive qualitative method. The data was transcribed into written transcript, and then was identified, selected, and also classified based on the analyzing needs which was relevant to the topic of the research. The gathered data was analyzed by using the mode from Miles and Huberman (2014) through the follow steps: data reduction, data description, and data classification.

\section{FINDINGS AND DISCUSSION}

\section{Findings}

\section{The Types of Code-switching in the Classroom}

The types of code-switching found through observation in the classroom seemed to fulfill all the code-switching types proposed by Poplack (1980), namely: (a) inter-sentential code-switching, (b) intra-sentential code-switching, and (c) tag-switching. Yet the first type of code-switching (intersentential code- switching) was extended as it has two forms of appearance in the classroom case; 1) inter-sentential code-switching between the sentences without inserting new information and 2) inter-sentential code-switching between sentences which inserts new information.

\section{Inter-sentential Code-switching}

\section{a. Code-switching between the Sentences without Inserting New Information}

This type of code-switching was frequently appeared $15 \%$ in the classroom likely for two aims. Firstly, it could help the teachers in delivering the information and instruction, thus the materials or the instructions was expected to become easier to be understood by the students. Secondly, it could be appeared also in the teachers' attempt to get respond from the students about the information or instruction which had been explained.

\section{b. Code-switching between the Sentences which Inserts New Information}

The alternation of the code was appeared $15 \%$ between the codes accompanied by some new information or instructions. The main purpose of this switching was mainly objected for the 
communication strategy to lead the students to be focus and to gather the students"e attention rather than maintain the comprehension of the students.

\section{Intra-sentential Code-switching (Translations of Words or Phrase Substitution within a Sentence)}

This type was applied $20 \%$ by the teachers through switching the two codes within a single sentence. The purpose of this type was to assist the students to understand the meaning of certain difficult English words. The factor using of this switching was easily observed for the sake of the ease of access into those words which was being discussed or the words which was connected to the topic which was being raised.

\section{Tag-switching (Interactional Fillers Code-switching)}

These fillers 50\% occurred one after another between English into Bahasa Indonesia or vice versa. Thus, there was often found the Indonesia fillers used within English sentences and conversely, there was also the possibility of the use of English fillers into the Bahasa Indonesia. From the data of the percentage above, the dominant types of code- switching used by the English teachers in the foreign language classroom is tag- switching or interactional fillers code-switching.

\section{The Factors Triggering the Teacher to Use Code-switching in the Classroom.}

\section{The Students' Ability in English Are Not the Same}

The teachers realize that competence of their students is not equally good. The classroom situation was often found very heterogenic. The teachers sometimes found that there were some students who cannot follow the teaching process if the use English the most of the time during their language between English and Bahasa Indonesia to solve this condition.

\section{Code-switching Emerges Automatically or Unconsciously}

This factor was very much related to the teachers" psychologically habit in using their mothertongue outside the classroom. Thus, the teachers often altered their language into their mother-tongue unconsciously.

\section{Helping the Students to Share Their Ideas}

This reason commonly appeared either in speaking activity or writing activity which require the students to express their ideas. Often it simply can be found some students who were hesitant to share their opinion, this might be caused by their language competency itself. And also, it seemed to be affected by the students' behavior to think about their ideas in mother-tongue. Thus, in simulating the students to express their ideas, the teachers often applied code- switching in order to improve and develop the students ${ }^{\text {ce }}$ fluency. 


\section{The Functions of Code-switching in the Classroom}

The data about the functions of code-switching in the classroom which had been gathered showed that all the functions of code-switching proposed by Sert (2005), namely: (a) topic switch, (b) affective function, and (c) repetitive function.

\section{Topic Switch}

The researcher found that the English teachers switch their code, when they try to get their students keep paying attention to the teaching materials or the instructions. This is found mostly related to the topic switch. When the teachers saw students, who did not pay attention to their explanation, then they switched their code into Bahasa Indonesia and usually accompanied by state of anger. The code-switching from English into Bahasa Indonesia which was used by the teachers aimed to get the students to pay more attention to the lesson which was being explained by the teachers.

\section{Affective Function}

In this function, English teachers used code-switching in order to build solidarity and intimate relations with the students. This function shows the fellowship between the teachers to their students. The teaching materials which had been presented in English before was often switched into Bahasa Indonesia and even into the local language of the students by the teacher. Through this way, the teachers basically intended to be more intimate with their students.

\section{Repetitive Functions}

In this case, the teachers use code-switching in order to transfer necessary knowledge for clarification. The clarification was intended to get the students to able to gain the clarity about what the teachers referred to and what the teachers expected the students supposed to do. This function was implemented by the teachers by using the counterpart of the words that the teachers had said in English before into Bahasa Indonesia. The switching of the code was meant by the teachers to emphasize what they were trying to convey.

\section{Discussion}

\section{The Types of Code-switching in the Classroom}

The data about the utility of code-switching in the classroom which had been gathered showed all the types of code-switching proposed by Poplack (1980), namely inter-sentential code-switching, intra-sentential code-switching, and tag-switching, simply occurred in the classroom. The first type is inter- sentential code-switching (without inserting new information or textual instruction and which inserts some new information or textual instruction). The second type is intra-sentential codeswitching or the translation or the substitution of a word or phrase within a single sentence. Whereas, the last one implicated the switching fillers which most of them are discourse makers or verbal formulation for the class management or material instruction, this type is called tag-switching. These types will be explained specifically as following. 


\section{Inter-sentential Code-switching}

a. Code-switching between the Sentences without Inserting New Information or

\section{Textual Instruction}

This type of code-switching was usually occurred in the classroom likely for two objections. First, it would help the teacher to convey the information and lubricated the information or instruction become easier to be understood by the students. Another possibility was that some teacher attempted to get respond from the students about the information or the instruction which had been told.

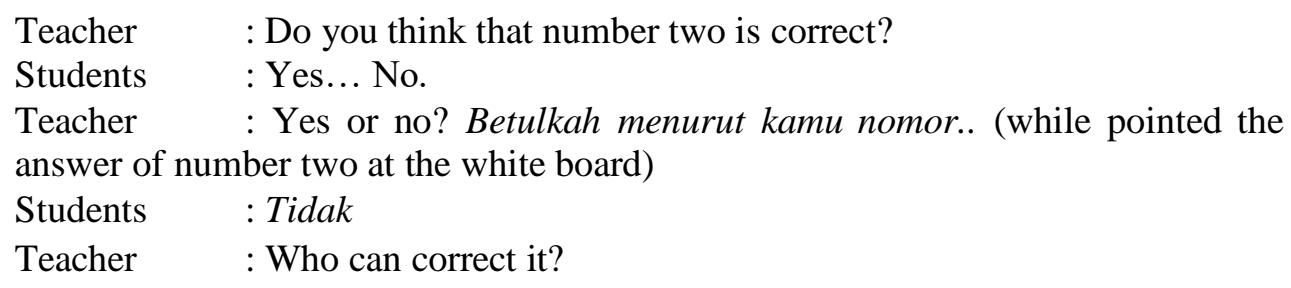

From the example above, the teacher switched their code to make the explanation or instruction comprehensible for the students. Thus, the students were expected to able to understand the teaching material or instructions better, and then they were also expected to be able do the instruction correctly.

This is type of code-switching proposed by Poplack (1980) which is relevant with the function of code-switching (repetitive function) proposed by Sert (2005). In it, the teachers switched their code without insert new information for clarity their statement or explanation which had been stated before and had made the students confused.

\section{b. Code-switching between Sentences which Inserts New Information or Textual Instruction}

This type of code-switching, the alternation of language is occurred between two codes accompanied by some new information or textual instructions were presented. Therefore, the main purposed of this switching is not to mountain the comprehension of the students instead it was mainly objected for the communication strategy to lead the students to be focus and to gather the students' attention.

Teacher Today, I would like to tell about poem and poetry. Biasa anda
mendengar orang membuat sajak, itu adalah bagian terkecil dari
puisi. Kalau dia sajak biasanya dia bersifat sederhanaa dan
pengandaian. Kalau dia puisi berarti dia lebih memiliki makna
yang mendalam.
: Before coming to the real reading text.. lettes go to the activity
one..
There is a special picture. I think that ini adalah legenda, bahkan
kalian telah menjawab soal yang saya berikan tadi.

The examples above showed that the teachers make the explanation was more comprehensible for the students. They tried to construct pleasant classroom restated through using Bahasa Indonesia. The explanation in English was often switched in Bahasa Indonesia in order to create a comfortable situation for the whole class. 


\section{Intra-sentential Code-switching (Translation or Word/Phrase Substitution within Sentence)}

This type of code-switching was done by the teachers to switch the two codes within a single sentence. The purpose of this type was to assist the students to understand the meaning of certain words which is considered as difficult words in English. Yet in the case of language used as the instruction is the mother tongue of the students and teachers then the reason using this switching was easily observed for the sake of ease of access into those words which was been discussing or the words which was connected to the topic which was been rising.

1. According to the legend, bagaimanakah Tangkuban Perahu ini tetap eksis?

2. Kalau artinya curse dalam bahasa Inggris itu apa?

3. Jadi dipending dulu, nanti minggu depan ya!

4. Siapa lagi yang complain tidak ada pasangannya?

5. Menurut bacaan, kapan mereka celebrated the harvest?

6. The last number, kita melihat bagaimana untuk merayakannya.

7. Sekarang kita lihat ada two expressions dimana mereka semuanya masingmasing adalah sympathy expression.

8. Buat kalimat bagaimana kamu bersimpati terhadap something!

9. From five numbers, siapa yang jawabannya benar semua?

10. From five numbers, siapa yang jawabannya benar sетиа?

The data showed that this type of code-switching was dominated by the sentence which is its language matrix is the mother-tongue of the students and the teacher (Bahsasa Indonesia). Whereas the use of sentences which had the English words as the language matrix was simply limited. This pattern was used by the teacher only if they wished their students said the words' counterpart in English from the other words which had been discussed before. This pattern also might occur when the teacher tried to connect to the students' response.

Students : Kejadiannya menarik

Teacher $\quad$ : Is it menarik? Seperti yang terlihat pada bacaan...

Form the data which had been gathered, the researcher can be concluded that the teachers teaching English in the high school tend to avoid the switching of the words from Bahasa Indonesia in to the English. Still conversely the switching from English into Bahasa Indonesia could be easier occurred. This is related to the different position of the two codes, where English is considered to be the target language in the classroom. The use of English which is learned formally as the target language in the classroom demands the students and the teachers to emphasize the formal and proper use of the target language. Also, the achievement of the language learning is indicated by the rate of accurate target language form showed by the speakers. Consequently, the speakers who mix the use of Bahasa Indonesia words into the English sentence psychologically seem to show the target language deficiency by the speakers resulting in teachers"e attempt to avoid it.

\section{Tag-switching (Interactional Fillers Code-switching)}

The use of discourse sign or interactional fillers from the two codes was frequently used by the teacher also. These fillers are occurred one after another between English into Bahasa Indonesia or 
vice versa. So that, there was often found the Indonesia fillers " $y a$ " or "jadi" used within English sentences and conversely there was also the possibility of the use of English fillers into the Bahasa Indonesia, such as "now", "so" or "then" followed by Bahasa Indonesia sentence.

The data showed that the teachers teaching English in classroom tended to use interactional fillers in Bahasa Indonesia more frequently than English fillers. Yet, these were mostly contributed by fillers such as " $y a$ " and "oke" which is belonged by the two codes. Because these fillers exist in both codes and the only difference between these codes is the pronunciation, there was the teachers ${ }^{\text {e }}$ tendency to choose the Indonesian version of these fillers, this might be because it was easier to pronounce. Here, it is important to emphasize that the teachers in utilizing the code-switching in the classroom must consistently notice and demonstrate that these two codes have different linguistic system to avoid mother- tongue interference into the target language. The teachers should show the difference between the pronunciations of "oke" in Bahasa Indonesia from its English "okay" and " $y a$ " in Indonesia from "yeah" in English.

This is type of code-switching proposed by Poplack (1980) which is relevant with the factor (lack of vocabulary) triggering the teachers to use code- switching by Holmes (2013). The teachers use interactional fillers because they could not find the proper words in English to explain what she/he meant.

\section{The Factors Triggering the Teacher to Use Code-switching}

\section{The Students' Ability in English Are Not the Same}

The teachers said that in the classroom, the situation is very heterogenic where there are some of the students have good enough ability English since they have ever taken an English course while some the others are still do not have the same ability in it. Thus, when the teachers give explanation or instruction, they tended to shift their language from English into Bahasa Indonesia to overcome such this condition.

Teacher $\quad$ : ......situasi di kelas kita yang heterogen, jelas mempengaruhi penggunaan bahasa di dalam kelas......

The teachers were also difficult to present the teaching materials most in English. There are students still cannot understand the lesson well if it was explained in English. Thus, to overcome this situation, the teachers not only used English in presenting the materials but also Bahasa Indonesia.

\section{Code-switching Emerges Automatically or Unconsciously}

The teachers realized that they sometimes still cannot stay discipline in using the target language, so that they often changed her code from English into Bahasa Indonesia unconsciously. It might be affected by the teachers"e habits in using the mother-tongue outside the classroom. It is also sometimes influenced by the teachers ${ }^{\text {ee }}$ local language, in this case Buginesse.

Teacher $\quad:$.....penggunaan bahasa secara bergantian di dalam kelas itu tidak dapat kita hindari. 
In addition, sometimes code-switching seemed to emerge completely automatically, without any preparing cues or flagging, and interestingly, these instances of automatic seemed to pass without specific attention from listener, which would suggest that code-switching is an activity from teachers in the classroom.

\section{Helping the Students to Share Their Ideas}

The teacher realized that most of their students are still influenced by their mother-tongue in developing their ideas in learning English particularly when discussing a certain topic or presenting it in written form. Thus, the teachers often tried to help the students to improve and develop the students ${ }^{e e}$ opinion by using Bahasa Indonesia.

Teacher $\quad$...ada kalanya mereka menjawab apa yang ditanyakan dalam
bahasa Indonesia, dan kita sebagai guru tentu saja
mengartikannya ke dalam bahasa Inggris, dan siswa juga
terpancing untuk menggunakan bahasa Inggris...

According to the teachers, the most important thing in the classroom is that the students can communicate and understand each other during the teaching- learning process.

\section{The Functions of Code-switching in the Classroom}

\section{Topic Switch}

From the data gathered through observation, the researcher inferred that the English teachers will switch their code, usually from English into Indonesian, if they try to get their students pay attention to the teaching materials or the instructions mostly related to the topic switch.

The $1^{\text {st }}$ example:

Teacher : (after giving the students the copy of the teaching materials) Now, I'll give you the text and you read this text. Duduk berhadapan..pindahkan kursinya cepat!

The $2^{\text {nd }}$ example:

Teacher : The word curse synonym to? The word curse.. Ada apa itu? (while turning to the students who make some noise) the word it synonym to??

Students : Word from god for punishment..

Teacher : Good. Apa di belakang itu?? (the teacher waited for the students to remainquite)

From the first example, when the teacher gave the students the copy of the materials to the whole class, the students who distributed the sheets move slowly then the teacher suddenly instruct him into faster, in Indonesian code furthermore the distribution of the copy moved quickly.

In the second example, the teacher felt that the classroom was disturbed by the noise done by two students sitting back of the classroom. At that moment, the teacher was using English code to interact with the students but when he reprimanded those students, he tended to switch the code into Bahasa Indonesia. This strategy apparently was effective enough to control the students and get the students pay attention. 


\section{Affective Function}

In this function, English teachers used code-switching in order to build solidarity and intimate relations with the students. In this sense, one may speak off the contribution of code-switching for creating a supportive language environment in the classroom. This function shows the fellowship between the teachers to their students. The teaching materials which had been presented in English before was often switched into Bahasa Indonesia and even into the local language of the students by the teacher. Through this way, the teachers basically intended to be more intimate with their students.

Teacher : : when we are going to discuss about woman health. It is about how women do everything to keep beauty. Kita akan mendiskusikan tentang wanita dan kesehatan. Tentang bagaimana para wanita melakukan segala cara agar tetap cantik. So, I want you find out the information as much as you can and present your presentation today. Jadi saya ingin kalian mencari informasi sebanyak banyaknya yang kalian bisa dan presentasikan di depan kelas... It is an interesting topic, I think.

From the example above, code switching function in affective function was applied by the teachers in order to be more intimate through switch their explanation in Bahasa Indonesia to their students.

\section{Repetitive Function}

The other function of code-switching in the classroom is repetitive function. This function, the teacher switched their code for clarity their statement or explanation which had been stated before and had made the students confused. Through this clarification, the students could gain the clarity about what the teachers' mean and what was the teacher expected the students should do.

Teacher : (after writing and explaining two sample of the English sentences on the whiteboard) so, this sentences is the same with the first sentence. To show or express the activity that will be being done in the next time or future time. Is there any question? Ada yang bertanya tidak tentang penggunaan dan form dari future continous tense? Jadi, coba jelaskan kapan kita gunakan kalimat future continous tense? Nah... kapan digunakan? Untuk menunjukkan kegiatan atau aktifitas yang akan dilakukan pada masa yang akan datang dimana aktifitas itu kita rencanakan atau sebaliknya.

The teacher found the same case. But in this situation, the teacher directly clarified her statement using Indonesian words. In other words, she did code-switch to make her statement understandable for the students.

This function was implemented by the teachers through finding the counterpart of the words that he/she had said in English before into Bahasa Indonesia. To emphasize what the teachers ${ }^{\text {ee intention }}$ toward the statements which they have been used before, the teachers often repeated those statements in Bahasa Indonesia. The switching of the code was meant by the teachers to emphasize what they were trying to convey. This is often used by their statements in Bahasa Indonesia after the English form. 


\section{CONCLUSION}

The types of code-switching occurred by the English teachers in the foreign language classroom setting is mainly in three types, where the types of code- switching purposed by Poplack (1980). These types are: (a) inter-sentential code-switching, (b) intra-sentential code-switching (translation or word/phrase substitution within a sentence), and (c) tag-switching (interactional fillers codeswitching). Yet the first type of code-switching (inter-sentential code-switching) was extended it has two forms of appearance in the classroom case; 1) inter-sentential code-switching between sentences without inserting new information, and 2) inter-sentential code-switching between sentences which inserts new information. The teachers do code-switch generally triggered by some factors, the factors proposed by Holmes (2013), they are: (a) rhetoric reason, (b) differences of status and formalities, (c) to quote other statements or proverbs, and (d) lack of vocabulary. And another the factors also gather from the classroom setting are: (a) the students' ability in English was not the same, (b) code-switching emerges automatically or unconsciously, and (c) helping the students to share their ideas. The functions commonly used by the English teachers in the foreign language classroom purposed also for some motive, these functions were: (a) topic switch, (b) affective function, and (c) repetitive function.

Teacher should not evade the existence of code-switching in teaching English in the classroom as it has many advantages in helping the students to comprehend most of the teaching materials in the classroom. Code-switching can be applied when the teacher explains the materials or give an instruction to the students. Teachers can use code-switching to lubricate the communication with their students in order to maintain the classroom's situation. And as the result, it is expected that the students will be able to be accustomed to communication in the classroom. For further research, it may be of interest to investigate further analysis of code- switching in the students' attitude toward the use of code-switching by English teachers in the foreign language classroom.

\section{REFERENCES}

Al Bulushy, Z. (1997). Bilingual Education and Code-Switching. Journal of Multilingual and Multicultural Language Development 10 (2): 117 - 126.

Bloom, Jan Petter and Gumperz, John. (1972). Social meaning in linguistic structures: Code-Switching. Norway.

Cook, V. 2002. Potraits of L2 User. Clevedon: Multilingual Matters.

Du Bois, John W. 2006. Transcription and the Delicacy Hierarchy: What is to Represented?. Paper given at Linguistic Society of America Annual Meeting: Albuquerque, NM.

Gay, L.R. (1995). Educational Research: Competencies for Analysis and Application. United States of America. Prentice-Hal. Inc.

Gay, Mills, and Airasian. (2006). Educational Research: Competencies for Analysis and Application (Eighth Edition). United States of America. Pearson Prentice Hall, Inc. 
Gulzar, M. A. (2010). Code-Switching: Awareness about Its Utility in Bilingual Classrooms. Bulletin of Educational Research. Vol.32, No. 2 PP. 23-44.

Gumperz and Hernandez, Chavez. (1972). The Encyclopedia of language and linguistics. Oxford: Pergamon Press.

Gumperz, John J. (1982). Discourse Strategies. Cambridge: Cambridge University Press.

Holmes, J. (2013). An Introduction to Sociolinguistics. New York: Longman. Jingxia, Liu. (2010). Teachers' Code-Switching to the L1 in EFL Classroom. The Open Applied Linguistics Journal. Vol.3.

Kim, E. (2006). Reasons and Motivations for Code-Mixing and Code-Switching. Issues in EFL. Vol. 4, no. 1.

Miles and Huberman. (2014). Handbook of Qualitative Research. California: Sage Publication Inc.

Offiong and Okon. (2013). Code Switching as a Countenance of Language Interference: The Case of the Efik Bilingual. International Journal of Asian Social Science 3(4): 899-912.

Pineda, D. (2008). Code-Switching in the Kola Peninsula. The Internet Online: http://www.david.pineda.hum.uit.no.

Poplack, Shana. (1980). Sometimes I'll start a sentence in Spanish Y TERMINO EN ESPANOL: toward a typology of code-switching. New York.

Qing, X. (2010). To Switch or Not to Switch: Examine the Code-Switching Practices of Teachers of Non-English Major. Canadian Social Science. Vol. 6 No. 4.

Rankema, Jan. (1993). Discourse Studies: An Introductory Textbook. Amsterdam: John Benjamins Publishing Company.

Sert, O. (2005). The Function of Code-Switching in ELT Classroom. The Internet TESL Journal, Vol. XI, No. 8.

Shin,S.J. (2005). Developing in two languages: Korean Children in America, Clevedon. UK: Multilingual Matters.

Skiba, R. (1997). Code-Switching as a Countenance of Language Interference. The Internet Online: http://www.melbourne.starway.net.au/.

Thomas, S, G. (2001). Language contact, an introduction. [e-book] Edinburgh: Edinburgh University Press Ltd. Available through: http://books.google.com/.

Von, V. (2004). "I Can Speak German-Und Deutsch” The Development and Use of Code-Switching among Simultaneous and Successive English-German Bilingual Children. Hannover.

Wiradisastra, G. (2006). A Preminilary Study of Code-Switching in the Speech of an Indonesian Bilingual. University of Indonesia.

Yletyinen, H. (2004). The Functions of Code-Switching in EFL Classroom Discourse. University of Jyvaskyla.

Youkhana, S. (2010). Code-Switching in the Foreign Language Classroom. Höstterminen. 